\title{
Exploring the Readiness of Betawi Cultural Village as a Sustainable Cultural Tourism Destination in Jakarta
}

\author{
Dinamayasari \\ Bogor Institute of Tourism (STP Bogor) \\ J1. Curug Mekar 17 Yasmin, Bogor-West Java, Indonesia \\ dinamayasari3@gmail.com
}

\begin{abstract}
Utilization of cultural resources at a tourism destination will create an appropriate alternative solution for areas who have high value of historical and cultural. Many studies support that the development of culture-based tourism destination would strengthen the culture. The linkage of cultural and tourism it is also occur during interaction between tourists and the communities attended or cultural performances being visited. "A balance is needed between the tourist, the experience of the culture visited and the host community. The tourist, the culture and the community dependent upon one another. Cultural tourism improved economical development of the local community" (Richard,2007:36). Indonesia famous for its rich and diversity in traditional culture one of them is Betawi culture. Betawi culture is the embryo culture of Jakarta as the capital city of Infonesia. Situ Babakan Betawi Cultural Village district located in the Srengseng Sawah, South Jakarta. Since the beginning, the purpose of establishment of Situ Babakan Betawi Cultural Village has been designated as the Cultural Village to preserved indigenous Betawi traditions and culture such as arts, custom (tradition), folklores, architectures, cuisine and others. Unfortunately, Situ Babakan has not yet become a major tourists attraction in Jakarta. The purpose of this research is to explore and analyze the readiness of Situ Babakan Betawi Cultural Village as a sustainable cultural tourism destination in from perspective of local community, the management and the government. Tourist attractions and activities, accommodation, other tourist facilities and services, institutional elements, transportation facilities and services, other infrastructure as well as natural and socio-economic environment are among destination components were used to explore and analyze its sustainable development. The research used descriptive qualitative approach combine with simple quantitative method, where some of local communities have been chosen as sample to fill-out the ended questionnaires and guided to ensure that any questions have the same perception. In the final analysis, we found that Situ Babakan Betawi Cultural Village needs to improve some destination components, in order to become a sustainable cultural tourism destination.
\end{abstract}

Keywords- Cultural Tourism Destination, Betawi Cultural Village, Components of a Tourism Plan , Sustainable Tourism Development

\section{INTRODUCTION}

\section{A. About Sustainable Tourism Development, Cultural} Tourism and Jakarta-Indonesia

„Sustainable tourism development can be thought as meeting the needs of presents tourists and host regions while protecting and enhancing opportunity for the future" (The Tourism Stream Action strategy Committee of the Globe'90 conference,1990). Basiccally, the sustainable tourism development concentrate on increasing opportunities for employment, income and improved local well-being while ensuring that all development planning and implementation reflect the optimum value of the natural, socioeconomic and cultural environment. According to Edward Inskeep in the book An Integrated Tourism Planning and Sustainable Development Approach (1991: 38-39) that's an attractive tourist destination and an ongoing need careful planning that includes nine components of tourist destinations, namely: 1 . tourists attraction \& activities 2. Accommodation 3. others tourist facilities and services 4. transportation facilities \& services 5 . Other infrastructures 6 . Institutional elements to develop and manage tourism necessary 7. Natural and socioeconomic environment 8 . domestic and international market group 9. Resident's use of tourist attractions \& facilities as shown in the following figure :

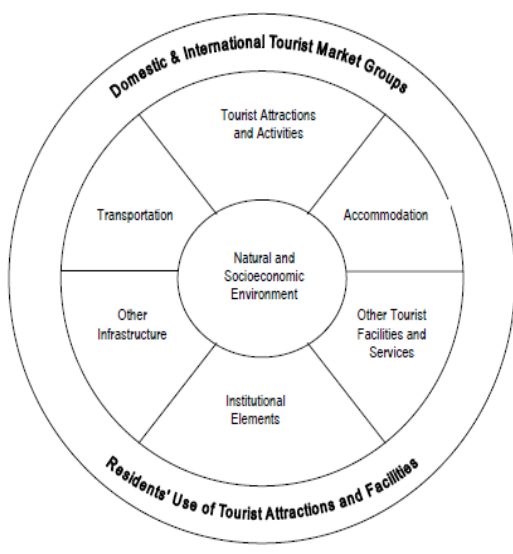

(Inskeep 1991:39)

Figure 1: Components of a Tourism Plan

Cultural tourism offers cultural attractions such as historical relics of ancient, sites, handicrafts, performing arts, rituals, and others are packed in such a way that it can easily be enjoyed by tourists and ultimately travelers gain cultural experience by seeing something considered unique, different, memorable and different sensations needed to enrich spiritual needs. Cultural products offered in the form of cultural 
attractions either tangible or intangible or abstract or concrete, which are also living culture and cultural heritage. Living culture is a culture that is still continuing, the elements that serve as an attraction among other traditions of a tribe, ceremonies and religious rituals, performing arts and so on, while cultural heritage is the cultural heritage of the past that made the appeal are relics history and archeology, cultural landscape, etc.

Jakarta is the capital city of Indonesia which is also as a center of government, economic activities, political, social and cultural. Jakarta is also one of the main gateways Indonesian tourism. There are various travel in Jakarta from nature tourism, historical tourism, shopping tourism, educational tourism, travel urbanized areas to culinary. In November 2012, Trip Advisor announced winners of the award "2012 Travelers Choice Destinations on the Rise" or tourist destinations rising popularity by travelers. Interestingly, Jakarta ranked at the top for a tourist destination in Asia, beating other tourist destinations such as Osaka, Kathmandu, Chiang Mai and Phnom Penh," said Jean Ow-Yeong, a spokesman for Trip Advisor. He added that the award was an appreciation of the city not only by increasing of tourist interest but also increasing positive feedback about the hotel, restaurant and activities to do in the cities. (Kompas.com.2012).

\section{B. About Situ Babakan Betawi Cultural Village}

The rapid development of the city should be offset by an increase in cultural values, environmental development and improvement of facilities and infrastructure was in a good management in order to preserve the traditional culture especially Betawi community, in order to enrich the culture of Indonesia (local government regulation, 2005). Betawi Cultural Village, is " Somewhere in Jakarta, which can be discovered and enjoyed life nuanced Betawi form: Community Betawi, natural beauty Betawi tradition of Betawi Culture and material is a source of information and documentation to Betawi-ness" (Department of DKI Jakarta City Planning and agencies, 2001) or in other words the Betawi Cultural Village is a neighborhood social life or the built environment nuanced Betawi, Betawi community inhabited by the fascinating natural beauty, diversity of traditions and culture of Betawi. Around year 1840, the term of village who comes from of Compound (Ismet et al , 1991 in Son 2006) are known for their original settlement growth natives ( Ambon, Bali , Bugis , and Malay ) in Jakarta to distinguish it from the term " city " for the settlement of Dutch citizens . Silas (1983) defines the word kampong or village as "a settlement has been roommates transform a rural village into an urban village with minimum but directly available urban services and utilities". According to England, " The rural tourism offer is distinctive and diverse, demonstrated the wide range of product and experiences offer, example including walking, adventure sports, horse-riding, fishing, boating, literary festivals, bird watching, conservation activities, business meetings and team building". Okech, Haghiri \& George (2012), "the purpose of a tourist village is to increase profits and prosperity for the people in the village and increase their participation in the development of tourism products."

\section{The Research Purpose \& Limitation}

The purpose of this research is to explore and analyze:1.The existing profile of Situ Babakan Betawi Cultural Village, 2. The perception from local community, the management and the government,3. The readiness of Situ Babakan Betawi Cultural Village as a cultural tourism destination in Jakarta. However this study is limited to analyze using the 7 of 9 components of the tourism development plan in sustainable development approach (Edward Inskeep, 1991)

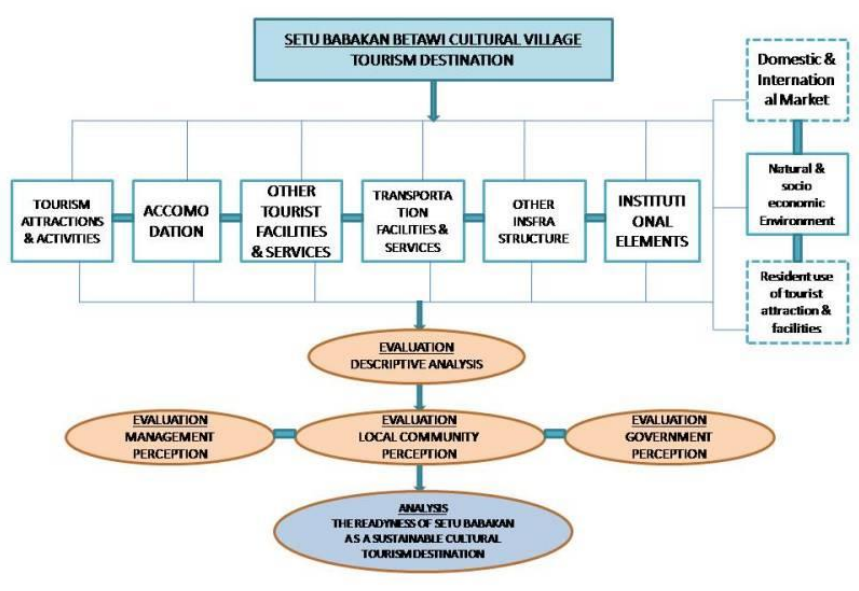

Figure 2: Conceptual Framework of The Study

\section{METHOD}

This research used descriptive qualitative approaccombine with simple quantitative method to get result of local community perception. The using of combination approach is to get a more accurate and complete result. Thirty (30) of local comunity have been chosen as respondents sampling to fill-out the ended-questionnaires in accordance with variable data that have been identified previously. During completing the questionnaires, all respondents were guided to ensure that any questions have the same perception. To get management and government's perception, in-dept interview has been done with an opened and ended-questionnaires also using direct observation to explore and analyze the existing conditions of Setu Babakan Betawi Cultural Village.

\section{A. Unit Analysis \& Time of the Study}

Location of this study is in Situ Babakan Betawi Cultural Village located on J1.. Mochamad Kahf II Serengseng Sawah, Jagakarsa, South Jakarta of DKI Jakarta province, Indonesia This research conducted in 2014, which later in the up- date with the most recent data in April 2016.

\section{B. Respondent}

Respondents are 30 local community with profile: $67 \%$ of $30-50$ years old and $33 \%$ of above 50 years old; $60 \%$ of male 
and $40 \%$ of women; $60 \%$ of secondary school education, $30 \%$ of high school education, $10 \%$ university level. $86 \%$ of respondents who are indigenous Betawi are food and beverage small vendors and small industrial entrepreneurs around Situ Babakan.

\section{FINDINGS AND DISCUSSION}

\section{A . Existing Profile of Situ Babakan Betawi Cultural Village}

Situ Babakan Betawi Cultural Village is an area where it can be discovered and enjoyed Betawi life nuanced forms: Betawi community, natural beauty, Betawi tradition, art and culture. Geographically, it is located at $10648^{\prime} 30$ " BT - 106 49 ' 50 " E and 06 20'07 " LS - 06 21'10 " latitude, has an area of approximately 289 hectares, which includes residential areas , facilities , city forests , Situ Babakan, Situ Mangga Bolong and springs which is managed in an integrated unity. Administratively, the Situ Babakan Betawi Cultural Village is located on Jalan Mochamad Kahf II , Srengseng Sawah Village, Jagakarsa, South Jakarta, Indonesia. Currently, Situ Babakan Betawi Cultural Village is more well-known for its beutiful lake surrounding by its lush green fruit trees than as a cultural village. Some directions to the area, just put the name of Situ Babakan. Physically, the Betawi nuanced can be seen at the design of main gate, some samples of Betawi traditional houses in the core area and A-Zone also some local community houses. Some resident houses are already have modern design building however still have Betawi decoration nuanced with its traditional gigi balang exterior ornament. Some Betawi ornaments such as chandeliers, tables, chairs, lamps or lanterns, is clearly visible on Betawi traditional houses in the core area. Betawi traditional clothes (Betawi batik, Betawi Pangsi and Sadariah) are still look worn by some staff of the institution and entrance guards. Batik, culinary, art and souvenirs with specific Betawi character are some interesting local home industries to be seen. During week-end, it can be found some traditional food-street sellers wear Betawi Pangsi attire while some residents wear ordinary clothes such as t-shirts and pants and moeslim clothes. Betawi language still can be heard especially in some of the stalls along the edge of the lake belongs to a native Betawi, management staff, entrance ticket guards and parking attendants. Re-construction Betawi tradition, performance art and culture that accompanied by the Betawi sounds of music like gambang keromong and tanjidor every Sunday afternoon, and children who practice Betawi dance or pencak silat martial art every Saturday is still become the main attraction that strengthens the culture of the Situ Babakan. Unfortunately, there is still no educational package tour or cultural activity package ready to be offered.

Since the establishment of Situ Babakan Betawi Cultural Village in 2001, the tourism destination was promoted locally and based on cooperation with the South Jakarta Education Department in creating of educational tours. The narrow of main road to the destination also in-availability of special parking facilities often causing congestion and poses a special problem. No transportation provided inside the destination, but we could find delman local transportation mostly on weekends. The delman are decorated with Betawi ornaments and the drivers wear pangsi cloth.

Some sample of Betawi traditional houses are could be used as home-stay that already completed with chairs, table, cupboard, mirror and toilet but still have no facilities of beds and room amenities also guests rules. For certain case, the management will invite and ask local residents, particularly those who has house with Betawi nuance architecture, to be used as a home-stay facilities.

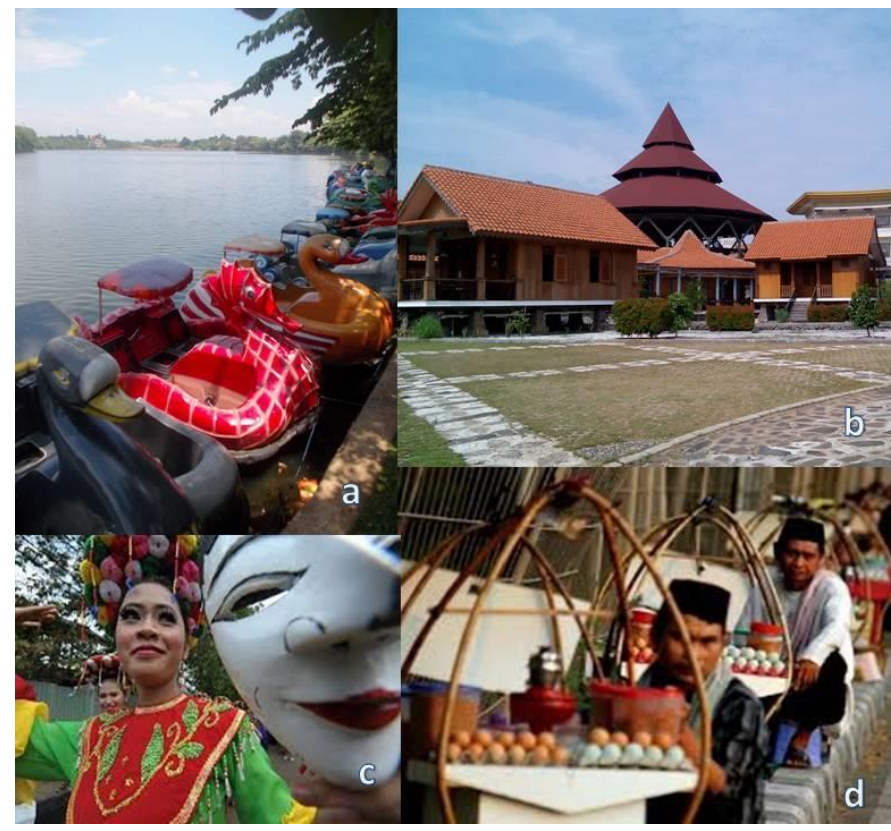

Fig. 1. Situ Babakan Betawi Cultural Village Attractions A:Natural Attraction \& Activity; b:Betawi Stilt Traditional Houses; c:Topeng Betawi Dance; d:Kerok Telor Traditional Cuisine

Among tourist facilities and services available are small local restaurants, small shops and stalls along the sidewalk selling various souvenirs, local food and drinks. Some of security staffs, 2 praying rooms, clean water facilities as well as 2 public toilets with 12 rooms can be found in the core area and zone-A. So far, there are no ATM or financial services, tourist information center, English speaking tourist guide, directions inside the area also location map of attractions and facilities. The newest facilities available are a library and an open air amplified theatre. The museum still can not be used while it is still used as a management office. In the component of other infrastructure, electricity facilities as well as water and sanitation systems are already exist evenly in the destination. Free access of wireless fidelity (Wi-Fi) has even provided in certain locations.

The management institution of Situ Babakan Betawi Cultural Village has been established by Jakarta Governor based on Decree no. 1193 in 2012, with an active board of management until 2016. The main function is to coordinate 
and care for the activities of the organization and Betawi community foundations to motivate, build and preserve Betawi culture. During It's management, the institution has a very limited function. His authority is prepare and sett a schedule of events, and sett procedures for using of the area while the governance of Situ Babakan lake is under the authority of Jakarta Provincial waterworks office and Landscaping Service office. Currently, the management of the institution is in transition because Situ Babakan Cultural Village management function will be held directly by the the government under Tourism and Culture Department who will be represented by the Implementation Units of Situ Babakan Cultural Village.

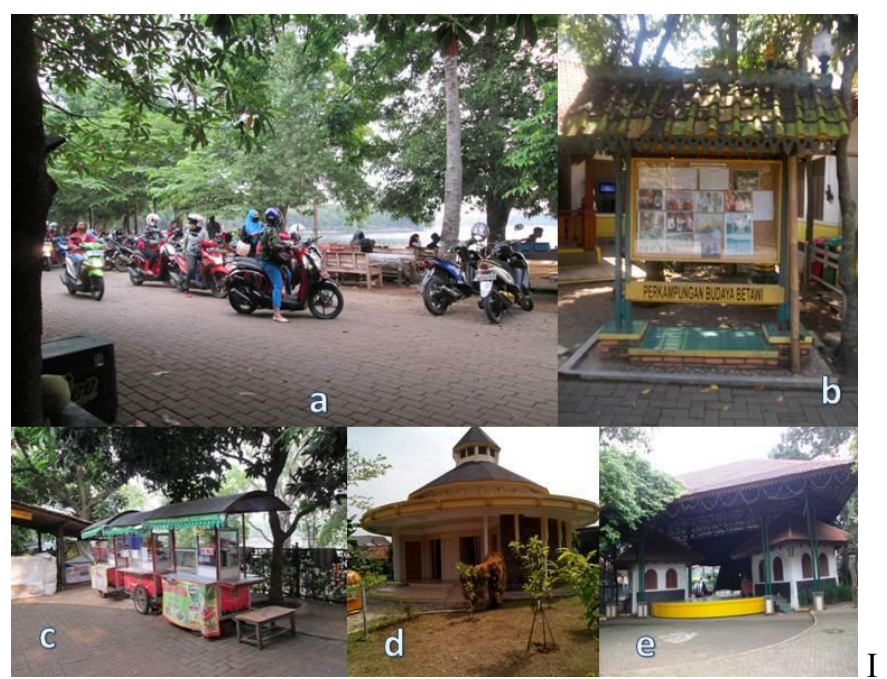

Fig.2. Among of Situ Babakan Facilities

a:Pedestrian Street as Parking Space; b:Information Board; c:Street Food; d:Public Toilet; e:Open-air Stage

Cleanliness efforts and dredging of Situ Babakan are conducted regularly by the Department of Water Management to maintain the cleanliness and beauty of the lake water as well as treatment of the trees by Landscaping Department. Betawi community still upholds the values of togetherness as well as family relation and has the typical characteristic which is based on Islamic ethics. Community business generally do household industrial activities in form of farmer groups as in the field of culinary, arts, agriculture and handicrafts and became one of the family income sources. However due to limitations in terms of resources, capital and knowledge, their industrial households are still small-scale nature and has not significantly contribute to the economic aspect. The existence of these farmer groups have also established a good social relations between communities. The number of immigrant communities that have diverse cultural and social backgrounds to some extent also influence the development of local communities culture and customs. The establishment of 289 hectares of the area as a Betawi cultural village tourism destination gave a positive influence on a variety of Betawi culture preservation. The management and government encouragement have stimulate the local community in forming culture groups or art studios in training children to learn various Betawi arts and culture.

\section{B. Perception from local community, the management and the government}

TABLE : LOCAL COMMUNITY PERCEPTION ON THE READYNESS OF STU BABAKAN BETAWI CULTURAL VILLAGE AS A SUSTAINABLE CULTURAL TOURISM DESTINATION

\begin{tabular}{|c|c|c|c|c|}
\hline Variabel & Indicator & Score & Mean & $\begin{array}{l}\text { Inter- } \\
\text { preted }\end{array}$ \\
\hline $\begin{array}{l}\text { 1.1.Natural } \\
\text { Attraction }\end{array}$ & $\begin{array}{l}\text { 1.1.a.Natural beauty } \\
\text { 1.1.b.Flora } \\
\text { 1.1.c.Special environment }\end{array}$ & 576 & 4.80 & $\begin{array}{l}\text { Very } \\
\text { Ready }\end{array}$ \\
\hline $\begin{array}{l}\text { 1.2.Cultural } \\
\text { Attraction }\end{array}$ & $\begin{array}{l}\text { 1.2.a Culture uniquenes } \\
\text { 1.2.b.Art \& handicraft } \\
\text { 1.2.c.Interesting economic } \\
\text { activity } \\
\text { 1.2.d.Cultural facilities } \\
\text { 1. 2.c.Cultural events and } \\
\quad \text { festival }\end{array}$ & 1016 & 3.81 & Ready \\
\hline $\begin{array}{l}\text { 1.3.Special } \\
\text { Type Attraction }\end{array}$ & $\begin{array}{l}\text { 1.3.a.Interesting local } \\
\quad \text { transportation } \\
\text { 1.3.b.Gastronomy } \\
\text { 1.3 c. Entertainment }\end{array}$ & 376 & 4.28 & $\begin{array}{l}\text { Very } \\
\text { Ready }\end{array}$ \\
\hline $\begin{array}{l}\text { 1.4.Tourist } \\
\text { Activities }\end{array}$ & $\begin{array}{l}\text { 1.4.a.Game } \\
\text { 1.4.b.Sports } \\
\text { 1.4.c.Culinary activities } \\
\text { 1.4.d. Events }\end{array}$ & 290 & 4.83 & $\begin{array}{l}\text { Very } \\
\text { Ready }\end{array}$ \\
\hline 2.Accomodation & Hotel/Home stay & 669 & 4.46 & $\begin{array}{l}\text { Very } \\
\text { Ready }\end{array}$ \\
\hline $\begin{array}{l}\text { 3.Other tourist } \\
\text { facilities and } \\
\text { services }\end{array}$ & $\begin{array}{l}\text { 3.1.Restaurants } \\
\text { 3.2.Art \& souvenir shops } \\
\text { 3.3. Tourist information } \\
\text { 3.4. Tourist guide } \\
\text { 3.5. Retail shops } \\
\text { 3.6. Praying facilities } \\
\text { 3.7. Financial facilities } \\
\text { 3.8. Security }\end{array}$ & 1118 & 3.11 & Ready \\
\hline $\begin{array}{l}\text { 4.Institutional } \\
\text { Elements }\end{array}$ & $\begin{array}{l}\text { 4.1. Human resource plan } \\
\text { \& development } \\
\text { 4.2. Organizational } \\
\text { structure } \\
\text { 4.3.Promotion \& marketing } \\
\text { strategy } \\
\text { 4.4 Policy \& regulation }\end{array}$ & 596 & 3.31 & Ready \\
\hline $\begin{array}{l}\text { 5.Other } \\
\text { Infrastructure }\end{array}$ & $\begin{array}{l}\text { 5.1.Clean water } \\
\text { 5.2.Electricity facilities } \\
\text { 5.3.Disposal } \\
\text { 5.4.Telecommunication }\end{array}$ & 399 & 3.63 & Ready \\
\hline $\begin{array}{l}\text { 6.Tansportation } \\
\text { facilities \& } \\
\text { services }\end{array}$ & $\begin{array}{l}\text { 6.1.Transportation to the } \\
\text { region } \\
6.2 \text { Transportation to the } \\
\text { destination } \\
\text { 6.3.Transporation within } \\
\text { the destination }\end{array}$ & 243 & 2.70 & $\begin{array}{l}\text { Ready } \\
\text { Enough }\end{array}$ \\
\hline $\begin{array}{l}\text { 7.Natural, Socio } \\
\text { economic } \\
\text { Environment }\end{array}$ & $\begin{array}{l}\text { 7.1. Positive impact control } \\
\text { 7.2. Negative impactcontrol }\end{array}$ & 471 & 3.93 & Ready \\
\hline Total & & & 3.98 & Ready \\
\hline
\end{tabular}

Result of the above table shown the average perception from local communities about the readiness level of Situ Babakan as a sustainable cultural tourism destination is 3.98 which can be interpreted as ready. It consist of components :: tourists activities (4.83); natural attraction (4.8); accommodation (4.46); special type attraction 4.28); natural 
and socioeconomic environment (3.93); cultural attraction (3.81); other infrastructure (3.63); institutional elements (3.31); other tourist facilities and services $(3,11)$; transportation and services $(2,7)$.

\section{B.2. Perception of the Management and Government}

The management institution of Situ Babakan Betawi Cultural Village officially established in 2001. The institution has an authority on managing the core area as well as preserving the Betawi traditional culture. From the management perception, Situ Babakan Betawi Cultural Village is ready as a sustainable cultural tourism destination. "Situ Babakan own infrastructure and some tourist facilities, but not all of them functioning optimally. There is no parking facilities available, no information center and museum still can not be opened yet. There are plenty of local food facilities but still have not found the clean and comfortable. We still lack human resources and also needs improvement on redesigning the landscape, especially along the edges of Setu Babakan" said Indra Sutisna as marketing and art committee (2016).

"Situ Babakan Betawi Cultural village is very ready with the concept and master plan for its development but not ready yet with the supporting facilities. So far we still using museum building as our working place so the museum can not be operated and the main road access to the destination is not suitable for bus or big vehicles and cause congestion. Situ Babakan Cultural Village become one of the four (4) Governor's prioritize on tourism development in Jakarta and currently we are still preparing it and hopefully will be ready in 2018", said Murliani (2016) as information and services of Implementing Units of DKI Jakarta Provincial of Tourism and Cultures Departments.

\section{IV.CONCLUSION AND SUGGESTION}

\section{A. The Conclusion}

1. Situ Babakan Betawi Cultural Village has a unique and a lot of potential as a tourism destination. Not only of its natural, activities and special type attractions but Situ Babakan has the uniqueness of Betawi culture such as the community, architectures, traditions, arts and crafts, cuisine, folklores and literature. Currently, the beautiful fresh water pond of Situ Babakan surrounding by the specific lush green fruit trees is still become the major tourist attraction. One of the reasons is because Betawi cultural performance held only once in a week every Sunday afternoon. Since the establishment of Situ Babakan Betawi Cultural Village in 2001, the tourism destination was slow on tourist facilities and infrastructures development, such as the un-availability of special parking facilities, un-availability of clean and adequate restaurant facilities, lack of tourist information within the destination such as information center and tourism map of the destination attractions and facilities, lack of directions and signed within the destination, no tour or cultural activity package that are ready to be offered and lack of human resources who understand the tourism.
2. The average perception from local communities shown that the readiness level of Situ Babakan as a sustainable cultural tourism destination can be interpreted ready (3.98). The highest average perception is the readiness on the natural attraction component (4.8) tourists activity ( 4.83 ) and accommodation (4.46) that all can be interpreted very ready. The lowest average perception is on the transportation and services component with category ready enough $(2,7)$. The other components that can be interpreted ready are facilities and other tourist services $(3,11)$, institutional elements (3.31), other infrastructure (3.63), cultural attraction(3.81) also natural and socioeconomic environment (3.93)

3. The readiness of Situ Babakan Betawi Cultural Village as sustainable cultural tourism destination, according to the management's perception is ready. At this time Situ Babakan Betawi Cultural Village already own facilities and infrastructure however still not maximum. Some of components are need to be improve such as un-availability of adequate parking facilities, museum, the clean and comfortable local restaurant and lack of human resources

4. Refer to the government's perception about the readiness of Situ Babakan Betawi Cultural Village as a sustainable cultural tourism destination is very ready, particularly on the master plan and development concept but is not ready in terms of supporting facilities such as the unavailability of management office, parking facilities, comfortable restaurant facilities and the main-road access to the destination is insufficient for large vehicles.

5. In the final analysis, based on in-dept observation and perception of the local community, the management and the government it could be concluded that at this moment the Situ Babakan Betawi Cultural Village is ready enough as a sustainable cultural tourism destination. Situ Babakan Cultural Village has such good attention to take care and preserve the natural and cultural environment, but there are still many factors need to be implemented and to be improved, such as transportation and services, facilities and other tourist services, accommodation as well as institutional elements and consideration of socio-economic environment. All the conditions illustrate that the readiness of Situ Babakan Cultural Village as a sustainable cultural tourism destination currently is not ready yet which is in line with the government's perception that states not ready. Meanwhile, there is a difference of perception of the local community and the management have expressed readiness can be considered reasonable because the perception is influenced by many things which are due to differences in the occupation, insight and also frame of mind. Overall, still need some efforts to create a mutual understanding, support and cooperation of all stake holders to generate the Situ Babakan Cultural Village become a sustainable cultural tourism destination. 


\section{B. The Sugestion}

To become a sustainable cultural tourism destination, the Situ Babakan Cultural Village not only has to concern on management and development on its attractions, services, facilities and infrastructures as well as tourist satisfaction but also have to do impact control on its natural, cultural and socio-economic environment. All could be well-implemented if there is a commitment and integrated supports among the management, local community, the government as well as private sectors. Socializations and support from individual tourists as well as establishing cooperation with nongovernment organizations (NGOs) would be much helped. The availability of adequate parking facilities is immediately required. Many vehicles parked alongside the lake, cause congestion and interfere with the comfort and safety of the tourists within the destination area. Some facilities and other tourist services should also be improved as the availability of the clean and comfortable restaurant facilities, accommodation, information facilities, other tourist facilities and landscape re-design along of Situ Babakan lake side.

\section{References}

[1] Inskeep,Edward.(1991). Components of Tourism Development. "Tourism Planning: An Integrated and Sustainable Development Approach.Canada. Jhon Wiley \& Son. 38-39

[2] Ismet et al.(1991) in Son 2006: 15

[3] Kompas.com.(2012).Jakarta.Destinasi Wisata yang Tengah Menanjak di Asia. http://otomotif kompas.com/read/2012/11/14/16080037

[4] Murliani.(2016. April29). DKI Jakarta Provincial of Culture \& Tourism Department. Personal Interview

[5] Okech, Haghiri \& George (2012). Tourist Village

[6] Peraturan Menteri Kebudayaan dan Pariwisata.(2009).tentang Pedoman Pelestarian Benda Cagar Budaya dan Situs Nomor : PM 49/UM.001/MKP/2009. Jakarta

[7] Peraturan Daerah Provinsi DKI Jakarta.(2005.no.3). Perkampungan Budaya Betawi Situ Babakan.

[8] Ritchie,J.R.Brent.\& Crouch,G. I.(2003).The Competitive Destination : A Sustainable Tourism Perspecive. CABI Publishing

[9] Richards,Greg.(2007).Cultural Attractions and European Tourism.Wallingford.CABI Publishing

[10] Revitalization of Indigeneous Culture in Paradigm Shift of Indonesia Tourism Development. (2010). International Seminar. Jakarta

[11] Sutisna,Indra.(2016.April 27). Management Institution of Betawi Cultural Village. Personal Interview

[12] Silas (1983) in Son. 2006: 12

[13] The Tourism Stream Action strategy Committee of the Globe'90 conference.(1990).Canada.An action strategy for sustainable developement. Tourism Planning An Integrated And Sustainable Development Approach.p.461 